\title{
Ineffective treatment of essential tremor with an alcohol, methylpentynol
}

\author{
HEIKKI TERÄVÄINEN,* JUHA HUTTUNEN,* PETER LEWITT $\dagger$ \\ From the Department of Neurology, University of Helsinki, Helsinki, Finland* and Department of Mental \\ Health, Lafayette Clinic, Detroit, Michigan, USA $\dagger$
}

SUMMARY Six patients with essential tremor tested in the therapeutic effectiveness of a 6-carbon alcohol, methylpentynol, $200 \mathrm{mg} /$ day, against placebo in a randomised double-blind clinical crossover trial. The effect of methylpentynol on postural tremor amplitude was not different from that of placebo.

Ethyl alcohol, like nonselective adrenergic betablocking drugs, decreases tremor amplitude in many patients with essential tremor. It has been reported that small amounts of alcohol can be more effective than propranolol therapy in the same patient. ${ }^{1} \mathrm{We}$ are unaware of clinical trials testing the possible therapeutic effectiveness of other alcohol derivatives in essential tremor. Therefore, we tested the efficiency of sub-hypnotic dosages of methylpentynol (fig) in a<smiles>C=CC(C)(O)CC</smiles>

Fig Structure of methylpentynol

randomised, double-blind and placebo-controlled trial. Methylpentynol has previously been used as an anti-anxiety and as a hypnotic agent. Prolonged use may lead to dependence of barbiturate and alcohol type, and with higher dosages it produces intoxication resembling that of ethyl alcohol. ${ }^{2}$

\section{Patients and methods}

The participants were six patients (one woman, five men; age range: 34-61 years, mean: 53.2) manifesting essential tremor

Address for reprint requests: Dr $\mathbf{H}$ Teräväinen, Dept of Neurology, University of Helsinki, Haartmaninkatu 4, 00290 Helsinki 29, Finland.

Received 26 March 1985 and in revised form 21 May 1985. Accepted 28 May 1985 known to respond to nonselective adrenergic beta-blocking drugs with about $50 \%$ decrease in their tremor. They were treated with methylpentynol in a randomised, placebocontrolled double-blind cross-over trial after providing informed consent. Major clinical characteristics of the patients are shown in the table: two had a positive and one a possible family history of tremor, and four reported considerable relief from small dosages of ethyl alcohol. The therapeutic effect of alcohol was mild, if any, in one and in another never had been tried.

Patients received $200 \mathrm{mg}$ methylpentynol (3-methylpent-1-yn-3-ol, $\mathrm{C}_{6} \mathrm{H}_{10} 0$ ) at $8.00 \mathrm{am}$ and $3.00 \mathrm{pm}$ in a mixture (Ataxir Medipolar) containing $100 \mathrm{mg}$ methylpentynol, $50 \mathrm{mg}$ valerian extract, $67 \mathrm{mg}$ glycerol and camphor in $1 \mathrm{ml}$ liquid or placebo, (same mixture devoid of methylpentynol). Each treatment duration was one week and no other drugs were allowed. Patients were tested prior to the drugs and at the 7 th day on each regimen. Their subjective evaluation of the tremor effect from the drug was assessed (no effect; worsened; slightly, moderately or highly improved) and the amplitude of their postural tremor was measured at the same time of the day (about noon) with an accelerometer (Grass, Model SPA-1) attached to the middle finger. The forearm was supported to the wrist with the patient sitting. The tremor signal was amplified, full-wave rectified and intergrated in 10 second periods to obtain a cumulative integral of the absolute acceleration $\left(\mathrm{m} / \mathrm{s}^{2}\right)$ of the tremor. The results are expressed as mean cumulative values of tremor recorded over a one minute period. The accelerometer was calibrated by gravity; a $90^{\circ}$ turn perpendicular to the sensitive axis causing an accelleration of $1 \mathrm{~g}$. Tremor frequency was calculated from recordings with a paper speed of $10 \mathrm{~cm} / \mathrm{second}$.

Since the value of tremor in the patient population was not normally distributed, Student's $t$ test was used in the statistical analysis after logarithmic transformation of the data. 
Table Effect of methylpentynol on tremor amplitude and clinical characteristics of six patients with essential tremor

\begin{tabular}{|c|c|c|c|c|c|c|c|c|}
\hline \multicolumn{3}{|l|}{ Patient } & \multirow{2}{*}{$\begin{array}{l}\text { Symptom } \\
\text { duration } \\
\text { (year) }\end{array}$} & \multirow{2}{*}{$\begin{array}{l}\text { Family } \\
\text { history }\end{array}$} & \multirow{2}{*}{$\begin{array}{l}\text { Alcohol } \\
\text { effect }\end{array}$} & \multicolumn{3}{|c|}{ Tremor amplitude $\ddagger$} \\
\hline$\overline{N o}$ & $\begin{array}{l}\text { Age } \\
\text { (year) }\end{array}$ & Sex & & & & Pretrial & Placebo & $\begin{array}{l}\text { Active } \\
\text { drug }\end{array}$ \\
\hline $\begin{array}{l}1 \\
2 \\
3 \\
4 \\
5 \\
6 \\
\text { Mean: }\end{array}$ & $\begin{array}{l}55 \\
61 \\
59 \\
34 \\
55 \\
55 \\
53 \cdot 2\end{array}$ & $\begin{array}{l}\mathbf{M} \\
\mathbf{F} \\
\mathbf{M} \\
\mathbf{M} \\
\mathbf{M} \\
\mathbf{M}\end{array}$ & $\begin{array}{c}5 \\
41 \\
40 \\
9 \\
15 \\
35 \\
24 \cdot 2\end{array}$ & $\begin{array}{l}* * \\
* \\
* * \\
* \\
-\end{array}$ & $\begin{array}{l}t \\
+t+ \\
+t \\
t+ \\
t+\end{array}$ & $\begin{array}{r}17 \cdot 3 \\
18.4 \\
14.6 \\
4.9 \\
12.8 \\
1.3 \\
11.6\end{array}$ & $\begin{array}{r}17.0 \\
19.6 \\
15.6 \\
4.4 \\
12.1 \\
1.9 \\
11.8\end{array}$ & $\begin{array}{r}20.0 \\
15.9 \\
13.1 \\
5.4 \\
11 \cdot 5 \\
3.3 \\
11 \cdot 5\end{array}$ \\
\hline
\end{tabular}

$++=$ Strongly positive effect against tremor.

$t=$ Mild beneficial effect against tremor.

** = Probable positive family history.

* = Possible family history.

$\ddagger=$ Mean $10 \mathrm{~s}$ cumulative integral of the absolute value of acceleration $\left(\mathrm{m} / \mathrm{s}^{2}\right)$.

\section{Results}

None of the patients regarded either drug or placebo as significantly effective, although two patients (cases 3 and 5) reported slight benefit while on methylpentynol. Objective measurements of tremor amplitude in each patient are shown in the table: no differences were observed in the mean tremor amplitude values, nor were there substantial differences between different visits in individual patients $(p>0.05)$. Mean tremor frequencies $( \pm S D)$ were $6.2 \pm 0.7$ (pretrial), $6.2 \pm 0.9$ (on placebo), and $6.2 \pm 0.7$ (on methylpentynol). Side-effects were mild and inconsistent. Two subjects (cases 1 and 3 ) reported tiredness, one dysphoria (case 2) and one (case 4) slowing of thought while on methylpentynol. Three patients (cases 1, 2 and 4) were somewhat tired, and one (case 2) also had dysphoria while on placebo.

\section{Discussion}

More than half of the patients with essential tremor find even small amounts of ethanol effective at suppressing these movements. ${ }^{13-7}$ Koller and Biary ${ }^{1}$ found that, with blood ethanol concentrations as low as $30 \mathrm{mg} / \mathrm{dl}$, subjects achieved an average of $67 \%$ reduction in tremor amplitude. It is unclear what aspects of ethanol pharmacology account for the antitremor property, as it clearly lacks the specific action of beta-blockade which renders propranolol and related compounds effective against essential tremor. While sedatives generally are not highly effective against essential tremor, the anti-convulsant primidone has been found to be quite useful, ${ }^{8}$ even with failure of response to beta-blockers. ${ }^{9}$ Of the metabolites of primidone phenobarbital seems to share the anti-tremor potency of primidone. ${ }^{10}$

In the case of methylpentynol (a molecule larger than ethanol), the alcohol group apparently does not confer that property of tremor control found with ethyl alcohol. The negative results in this trial (which included at least four subjects with ethanolresponsive tremor) are further evidence that the efficacy of ethanol is not a function of sedative actions but rather a more discrete pharmacological property. Other molecular mechanisms for ethanol effect could include effects on cell membranes at the level of the central nervous system.

We thank Signe and Ane Gyllenberg Foundation for financial support and Ms Susan Pihl for technical and secretarial assistance.

\section{References}

${ }^{1}$ Koller WC, Biary N. Effect of alcohol on tremors: comparison with propranolol. Neurology (NY) 1984; 34:221-2.

${ }^{2}$ Martindale W. In: Wade A, ed. The Extra Pharmacopeia. London: Pharmaceutical Press, 1977:763.

${ }^{3}$ Critchley M. Observations on essential tremor. Schweiz Arch Neurol Neurochir Psychiatr 1948;61:380-1.

${ }^{4}$ Critchley E. Clinical manifestations of essential tremor. $J$ Neurol Neurosurg Psychiatry 1972;35:365-72.

${ }^{5}$ Davis CH, Kunkle EC. Benign essential (heredofamilial) tremor. Arch Intern Med 1951;87:808-16.

${ }^{6}$ Growdon JH, Shahani BT, Young RR. The effect of alcohol on essential tremor. Neurology (Minneap) 1975; 28:259-62.

${ }^{7}$ Rajput AH, Jamieson H, Hirsh S, Quraishi A. Relative efficacy of alcohol and propranolol in action tremor. Can J Neurol Sci 1975;2:31-5.

${ }^{8}$ O'Brien MD, Upton AR, Toseland PA. Benign essential tremor treated with primidone. $\mathrm{Br}$ Med $J$ 1981; 282:178-80.

${ }^{9}$ Munro A. Essential tremor. Can Med Assoc J 1981; 125:958.

${ }^{10}$ Procaccianti G, Baruzzi A, Martinelli P, Pazzaglia P, Lugaresi E. Benign familial tremor related with primidone. $\mathrm{Br}$ Med J 1981;283:558. 